\title{
Uña de Gato: Fate and Future of a Peruvian Forest Resource
}

Wil de Jong, Mary Melnyk, Luis Alfaro Lozano,

Marina Rosales, and Myriam García

CENTER FOR INTERNATIONAL FORESTRY RESEARCH

Office address: Jalan CIFOR, Situ Gede, Sindangbarang, Bogor 16680, Indonesia Mailing address: P.O. Box 6596 JKPWB, Jakarta 10065, Indonesia

Tel.: +62 (251) 622622; Fax: +62 (251) 622100

E-mail: cifor@cgiar.org

Website: http://www.cgiar.org/cifor 


\section{Contents}

Summary 1

Introduction 1

The issues 2

Characteristics of the resource 2

Compounds and curative properties of uña de gato 2

Ecology of uña de gato 3

Prospects of the uña de gato industry 4

International trade and sales of uña de gato 4

Extraction and collectors $\quad 5$

National manufacturers and their trade $\quad 6$

United States manufacturers and distributors $\quad 6$

Sustaining the resource 6

Controlled extraction and management of uña de gato 6

$\begin{array}{ll}\text { Government actions to sustaining production } & 7\end{array}$

$\begin{array}{ll}\text { Root versus bark } & 7\end{array}$

$\begin{array}{ll}\text { Uña de gato propagation techniques } & 7\end{array}$

Policy and legal issues $\quad 8$

Permits and administration for collection, trade and export of uña de gato 8

Genetic and intellectual property rights $\quad 8$

Resolving the issues 9

Is the resource base being threatened?

$\begin{array}{ll}\text { The future of the industry } & 10\end{array}$

Benefit capturing among small-scale collectors $\quad 11$

Compensation for property rights 11

The proposed export ban $\quad 12$

Conclusions 12

Literature cited $\quad 14$ 


\title{
Uña de Gato: Fate and Future of a Peruvian Forest Resource
}

\author{
Wil de Jong ${ }^{1}$, Mary Melnyk ${ }^{2}$, \\ Luis Alfaro Lozano ${ }^{3}$, Marina Rosales ${ }^{3}$, and Myriam García ${ }^{3}$
}

\begin{abstract}
Summary
Uncaria tomentosa and U. guíanensis have been important in traditional healing in many South American countries. These species contain some sixty active substances which are widely tested for possible medical treatments. U. tomentosa has been traded from Peru until it reached a peak export of 726 tonnes in 1996. Government agencies and private companies have dedicated considerable efforts in trying to enhance production and sales of these species. At the national level, there has been pressure put on the government to allow legislation to prohibit the sales of the raw material of these species to capture larger shares of benefits for the national economy. Initially false conservation arguments were used as there is sufficient evidence to argue that at current harvesting levels there is no threat to the two species. Regional government agencies have promoted the production of the two species without having a clear picture of future demand, allowing the possibility that much of the future production will not have any demand. Both actions may possibly negatively affect the benefits that accrue to local collectors or producers.
\end{abstract}

\section{Introduction}

Uncaria tomentosa (Willd.) D.C. and Uncaria guíanensis (Aubl.) Gmel. are both known as uña de gato and are native to a number of Central and South American countries. The two species have been used as medicinal plants in several of the countries where they occur, but its local use has mostly been recorded from Peru. Among local traditional healers, but also in the lore on medicinal plants, it has been widely recognized as a powerful medicinal that provides relief for a number of infectious or rheumatic diseases.

Currently uña de gato, and especially Uncaria tomentosa is in demand in more than 30 countries outside Peru as teas, tablets or capsules, as well as in the country itself. This national and international appreciation for uña de gato is the result of its "discovery" by western medical sciences almost three decades ago. Now that an important industry providing a substantial source of income for collectors, traders, and manufacturers has developed around uña de gato, and that there is an everincreasing faith in the yet undiscovered healing potentials of the plant's compounds, it is the right moment to step back and take a broad look at the uña de gato industry, and to evaluate its possible future development.

This document intends to report on the current uña de gato industry in Peru and in the United States, the country that has so far been the largest importer of this medicinal. Its information has been collected from scientific and popular literature, government statistics, and from interviews with a large number of people who have some knowledge about uña de gato harvesting, trading, manufacturing of derivatives and their sale. These include people who are directly involved in any of these activities, as well as people who work at institutions that deal with natural resource utilization. This document also provides an analysis of this information, and the issues that need to be resolved to ensure that the uña de gato industry continues to grow sustainably, without overexploiting the resource base, and with broad and equitable sharing of benefits.

There are three institutions involved in the preparation of this report, and each have their own objectives for participating in this effort. The Instituto Nacional de Recursos Naturales (INRENA) is a Peruvian state agency that develops proposals for environmental legislation and natural resource management guidelines that are passed on to implementing offices of Peru's Ministry of Agriculture. INRENA is concerned that uña de gato exploitation is concordant with policies on Peru's natural resources. USAID's Global Environment Center provides technical backstopping to country office's initiatives that concern environmental resources. INRENA requested such technical support to aid in the development of regulations for uña de gato management. The Center for International Forestry Research (CIFOR) has become interested in uña de gato harvesting and trade because it is conducting research on the potential of secondary forest as an economic resource in Peru, Brazil, and Nicaragua. As uña de gato thrives in secondary forest vegetation, and currently has an important demand, the species appears to be a possible candidate for creating income from secondary forest. CIFOR has also an interest in uña de gato as a case study for its research on the potentials and trends of forest resources in the economies of low income groups, and as a case study

\footnotetext{
${ }^{1}$ Center for International Forestry Research

${ }^{2}$ USAID, Global Environment Center

${ }^{3}$ Instituto Nacional de Recursos Naturales
} 
for the need and possibilities of policy development concerning natural resources like uña de gato.

\section{The issues}

The three goals that should be met through any action or intervention in the current uña de gato industry are: (1) The resource base is harvested sustainably, i.e. the species is not threatened with biological extinction, nor are any organisms depending on uña de gato for its biological cycle affected by its harvesting. (2) Uña de gato will continue to benefit local collectors, i.e. their incomes obtained from this resource will increase, or larger numbers of low income people will be able to obtain extra income from uña de gato collection and/or production. (3) The uña de gato industry in Peru will continue or increase its current size, thus allowing a stable or increased employment for workers in that industry, as well as contributing to the national economy through sales to international and domestic markets.

These three objectives are not easily reconciled. Increasing the incomes for local collectors, traders, or manufacturers of derivatives will require the collection of greater quantities of uña de gato. If these were to come from natural populations, then that would increase the pressure on this forest resource. Neither are the objectives of the sustaining or increasing incomes for the small-scale collectors compatible with expanding the production of the manufacturing industry. Larger companies may take over harvesting and production which may eliminate the opportunities for small-scale collector or producers to obtain income from uña de gato. An important reason why companies would want to take over collection or production is that they believe that they can obtain better quality raw material, with higher active compound contents. This last issue is important for uña de gato manufacturers whose demand depends upon product quality to assure or increase incomes.

In order to address these issues, this report will first review some of the most important and available information on uña de gato. The following discussion is subdivided into four major themes: (1) some characteristics of the resource, (pharmaceutical and ecological properties of the species) (2) the prospects of the industry that has developed around uña de gato (international trade, extraction of the resource, and manufacturing of derivatives, United States manufacturers and distributors), and (3) actions that have been taken to sustain the resource base (indigenous management, government actions, propagation technology) and (4) policy and legal issues (administrative requirements for collection and trade, property rights). Using this information we will try to asses the several issues formulated above.

\section{Characteristics of the resource}

\section{Compounds and curative properties of uña de gato}

It is very difficult, if not impossible, to trace the origin of the discovery of uña de gato as a medicinal plant. Its local use for medicinal purposes in Peru has been reported among Ashaninka in the Chanchamayo, Perené and Tambo valleys and among Yanesha groups in the Palcazu valley. However, Vasquez (1989) also reports the utilization of Uncaria guíanensis among Boras, who live in the Amazon lowlands near the Colombian border. Balée (1994) reports the same species as a medicinal plant among the Ka'apor people, in the State of Marañao in Eastern Brazil. One can only speculate about who first discovered uña de gato therapeutic properties. It can be assumed that they have been known for a long time and have been shared among different groups in the region. This includes the indigenous non-tribal groups of Peru, the ribereños, or other migrants into the region. Uña de gato is also sold on the market in La Paz, Bolivia. Traditionally uña de gato is prepared as a decoction, boiling inner bark or root bark, or is macerated in an alcoholic beverage, using the locally produced sugarcane rum. This extraction method with alcohol results in a higher extraction of alkaloids then when decoctions are prepared with water (Dominguez 1997).

There appear to have been several independent initiatives to investigate the origin of uña de gato's healing potential. Arthur Brell, who had come to live in Peru in 1926 observed the use of "Zavenna rossa", supposedly uña de gato, as a contraceptive among Ashaninka women. In 1965, together with Dr. Eugene Withworth of the Great Western University of California he undertook an expedition to the Perené and Tambo valleys where they collected uña de gato samples and specimens (Zavala \& Zevallos 1996). On the other hand, Oscar Schuler also learned about uña de gato in 1969 , and he prescribed its decoctions to his father Luis Schuler Stadler. Luis Schuler was terminally ill from cancer, and suffering from rheumatism. The decoction allegedly cured Luis Schuler, who then continued to live for another fifteen years. This success lead Oscar Schuler, who was from Germany, but who had lived most of his life in Peru, to communicate this cure to Klaus Keplinger, who took specimens of the plant to Innsbruck, Austria, and eventually discovered several of the active alkaloids. Mr. Oscar Schuler also started a company that harvests uña de gato, and sells it in processed and unprocessed form inside and outside of Peru. The recent uña de gato boom has been attributed to the promotion of the species by Andres Garcia, a popular Mexican actor, who claimed to have been cured of prostate cancer in 1991.

The oldest literature source that Obregon (1995) mentions is a publication on Ourouparia guíanensis, an earlier name for Uncaria guíanensis, by Raymond 
Hamet from 1952. This study, in which leaves were screened, established the presence of the alkaloid rynchophyllin. During subsequent decades a number of studies reported on the alkaloids and procyanidins (e.g. Hemingway \& Phillipson 1974; Montenegro de Matta et al. 1976), quinovic acid glycosides that have anti-viral activity (e.g. Cerri 1988; Aquino et al 1989, 1991; Yepez et al.1991) and triterpenes that have antitumor activity (Aquino et al. 1990) of the two Uncaria species from South America. Research on the steroid fraction furthermore demonstrates the presence of Bsitosterol, campesterol and stigmasterol, and only traces of cholesterol. B-sitosterol is the principal sterol which has a moderate anti-inflammatory effect (Senatore et al. 1989). Duke (1992) mentions more than 50 chemical substances from uña de gato. Uncaria tomentosa and Uncaria guianensis differ slightly in their chemical composition, although there is currently no definite agreement on which species misses which of the many compounds that have been discovered in the two species. Some of the confusion over the composition of each species may be the result of changes in alkaloid composition of uña de gato during seasons and during individual plant's life cycles (Laus \& Kepplinger 1994).

Only since the 1980s did reports begin to appear on the therapeutic effect of specific uña de gato compounds. Wagner et al. (1985) report on the immune-stimulating activity of Uncaria tomentosa supposedly caused by oxindole alkaloids through a phagocytosis enhancing effect. Aquino et al. (1989) report on the anti-viral activity and on the anti-inflammatory activity and Aquino et al. (1991) of the quinovic acid glycosides of Uncaria tomentosa. Rizzi et al (1992) show that uña de gato has significant antimutagenic activities, possibly a result of its anti-oxidant properties that scavenge the singlet oxygens and other free radicals to which aging and cancers have been attributed. Results from Sandoval et al. (1997) also indicate that uña de gato protects cells from oxidative stress that causes cell death. They furthermore found that uña de gato given to rats reduced intestinal inflammation.

Peruvian researchers have been conducting clinical trials with Uncaria tomentosa and Uncaria guianensis decoctions, pills, or tablets. Costa Fazii (1989) demonstrated that uña de gato decoction appears to reduce the gastritic consequences of stress effects. Treatment with uña de gato pills reduced the inflammation of rheumatic arthritis (Castañeda et al. 1997) extra-articulary rheumatism, and osteoarthrosis (Pevez et al. 1997; Piscoya et al. 1997). Tests with alkaloids demonstrate positive effects on the inhibition of leukemia cells development, providing hope for leukemia treatment (Duke 1992). Otero (1996, cited in Zavala \& Zevallos 1996) holds that there is no evidence that uña de gato cures or reduces the risk of contracting cancer caused by smoking, or any other type of cancer. However, Mirez (n.d.) concludes that Uncaria tomentosa reduces pain, reduces the tumor mass, and reduces the metastasis in cancer treatment. It furthermore improves the effect of chemotherapy, radiotherapy and reduces side and toxic effects of any of these two treatments.

Summarizing its therapeutic properties, Obregon (1995) concludes that uña de gato seems to have positive effects for the treatment of arthritis, gastritis, dermatological infections and infections of the genital canals, asthma, gastric ulcers, diabetes, several cancers (bronchi-pulmonary, gastric and of the female genital canal), several types of tumors, viral infections, irregularities of the menstrual cycle, gonorrhea, convalescence and general debility. There is, furthermore, ample indication that possibly the combination of various compounds each with some antiinflammatory effect causes the significant antiinflammatory effect of whole uña de gato based preparations. There are also indications that the biological activities of uña de gato are increased by other synergetic characteristics, or that some compounds function as a vehicle for the active compounds. Also it cannot be excluded that some therapeutic activities of uña de gato may be caused by compounds that have not yet been discovered.

\section{Ecology of uña de gato}

Uncaria tomentosa and Uncaria guianensis are both lianas that derive their vernacular name from the cat's claw-like thorns that both species have in common. Both Uncaria species have been recorded in all Western countries from the American continent as far South as Paraguay, and as far North as Belize (Quevedo 1995; Zavala and Zevallos 1996). The most Eastern recording is from Marañao, Eastern Brazil (Balée 1994). In Peru, both species are found in the regions Loreto, Ucayali, San Martin, Pasco, Junin, Inca, Mariscal Caceres and Wari.

Uncaria tomentosa is found at higher altitudes, compared to Uncaria guianensis. Some disagreement, however, exists on altitudinal distribution of the species. Zavala and Zevallos (1996) report Uncaria tomentosa to occur between 100-995 m.above sea level (asl). Quevedo believes this last species occurs only between 100 and $500 \mathrm{~m}$ asl. while Maxwell (1961) reports it between 700 and $2500 \mathrm{~m}$ asl. Uncaria guíanensis is reportedly found at the low altitudes of the total geographic distribution of the two uña de gato species (100-800m asl, Zavala and Zevallos 1996), and is more widely distributed.

In Peru the two Uncaria species prefer Ortic Acrisols, Distric Cambisols and Fluvisols. However, Uncaria tomentosa is mostly found on high and hilly, welldrained terrain with high organic soil content, but in the 
regions of Loreto and Ucayali this species occurs also on levees in the flood plains of the major Amazon river systems. Uncaria guianensis on the other hand is more habitually found on flat or slightly undulating terrain with poorly drained soils (Zavala and Zevallos 1996).

Light requirements or tolerance are also different for the two species. Both species are heliophytes, but Uncaria tomentosa is the only one of the two species found in closed mature natural forest, or slightly disturbed forest. Uncaria guíanensis is almost only found in secondary forest (Quevedo 1995; Zavala \& Zevallos 1996). The species is also found alongside larger and smaller rivers (e.g. Balée 1994). On the other hand, Duke (1994) questions this restriction to more closed vegetation of Uncaria tomentosa. According to him, this species is the only one of the two Uncarias found in the lowlands of Panama, Honduras, Guatemala, Costa Rica and Belize. It is reported to become a troublesome weed in banana plantations in Central America (Standley and Williams 1975).

Both species are slightly different in size, and reproduction. Uncaria tomentosa reaches adult stage with a length between 10 and $30 \mathrm{~m}$, and a base diameter between $5-40 \mathrm{~cm}$. This species has appropriate thorns that allow it to climb to $20-30 \mathrm{~m}$ into the accompanying vegetation (Quevedo 1995). Uncaria guianensis, when adult, grows between 4 and $10 \mathrm{~m}$, and has base-diameter of $4-15 \mathrm{~cm}$. Compared to Uncaria tomentosa the species is slightly more characteristic of a creeper than that of a climber, due to the fact that its thorns are bent inwards. These thorns are less functional for lifting the stem up through the tree vegetation.

Where it is found in natural forest, Uncaria tomentosa has a density of two to eight adult individuals per ha. The low number of individuals is most likely a result of the limited opportunities of seedlings to grow well under shaded conditions (Quevedo 1995). On the other hand, Pro Naturaleza conducted inventories in Loma Linda with Yanesha, inhabitants of the the Palcazú valley, where 17 individuals per ha were found.

\section{Prospects of the uña de gato industry}

\section{International trade and sales of uña de gato}

The export of unprocessed bark, milled bark, or micropulverized bark of uña de gato require permits, registered by INRENA. The total weight that INRENA recorded were $200 \mathrm{~kg}$ in $1993 ; 20,743 \mathrm{~kg}$ in $1994 ; 726,684 \mathrm{~kg}$ in 1995 and 346,903kg in 1996 (Table 1). The FOB value of 1995 exports equalled US\$ 3.3 million (INRENA 1996). Unprocessed uña de gato was exported to only one country in 1993 (United States) and by 1996 its export increased to 26 countries. Although the total export in 1996 was only $48 \%$ of that in 1995 , the number of countries exported to increased. The decrease in amount in 1996 is largely due to a decrease in exports to the US; from $679,080 \mathrm{~kg}$ in 1996 to $160,694 \mathrm{~kg}$ in 1996 . This country changed from buying $93 \%$ of all the exported uña de gato in 1995 to only $46 \%$ of all the exported bark. Countries that imported over $5000 \mathrm{~kg}$ of uña de gato in 1995 were in order of decreasing quantity US, Chile, Mexico, Austria, Brazil, Japan, Spain, and Italy (statistics provided by INRENA 1997).

Explanations for why the total weight exported decreased between 1995 and 1996 differ. Some say that the high export to the US has saturated the North American market or there were stockpiles left over from 1995, while others argue that the entry of poor quality materials and products during the boom may have resulted in a loss of consumer confidence and also decreased demand. It was even mention that in 1995 , rumors began of a proposed export ban on unprocessed bark (to be discussed later in this document) that caused some importers to stock-up on the bark. Despite the decline in 1996, one of the co-authors of this paper was told by a U.S. distributor that it had received an order in early 1997 for 100 ton/month of uña de gato, which is more than any harvesting level that has occurred until now.

A change in the proportion of trade of different processed forms of uña de gato is indicated by the statistics provided in Table 1. The proportion of bark

Table 1. Uña de gato international trade

\begin{tabular}{|c|c|c|c|c|c|c|c|}
\hline year & weight [kg] & $\%$ bark & $\%$ grinded & $\begin{array}{c}\% \text { micro- } \\
\text { pulverized }\end{array}$ & $\%$ packed & $\%$ extract & $\begin{array}{l}\text { countries } \\
\text { exported to }\end{array}$ \\
\hline 1993 & 200 & nd & - & - & - & - & 1 \\
\hline 1994 & 20743 & 84.9 & - & 13.6 & 1.5 & - & 8 \\
\hline 1995 & 726684 & 89.6 & 4.6 & 5.3 & 0.5 & - & 24 \\
\hline $1996 *$ & 346903 & 80.3 & 15.2 & 3.5 & 0.8 & 0.1 & 26 \\
\hline price $S / .^{* *}$ & & $3.4 / \mathrm{kg}$ & $5.86 / \mathrm{kg}$ & $20.31 / \mathrm{kg}$ & $1.8 / 100 \mathrm{gr}$ & - & - \\
\hline
\end{tabular}


increased between 1994 and 1995, but declined again in 1996. The proportion of grinded bark being sold to foreign countries increased, but, surprisingly the proportion of micro-pulverized uña de gato exported decreased from 1994 - 1996. Only in 1996 did INRENA statistics provide any data on the sale of extract of uña de gato. These data do not convincingly support a shift towards exportation of more processed uña de gato, neither do they contradict such a trend. Some informants, however, foresaw a future shift towards an increased sale of uña de gato extracts, at the expense of unprocessed, or processed bark.

In 1995, INRENA gave 400 permits for the trade of uña de gato. These were given to 100 companies who exported uña de gato bark, grinded bark, or micropulverized bark. Only 12 companies sold packed uña de gato for direct sale. Ten of these did also sell micropulverized, grinded, or unprocessed bark. A total of 174 companies imported uña de gato in the respective countries (INRENA statistics) The uña de gato that was exported in 1995 came from 11 departamentos, the largest poltical units in Peru. Only five provided amounts above $10,000 \mathrm{~kg}$ of uña de gato: Ucayali (280,082), Huanuco (230,4521), Pasco (112,931), Junin $(44,362)$, and San Martin $(40,232)$.

Products were sold to Austria, Belarus, Bolivia, Bulgaria, Canada, Chechnia, the Dominican Republic, Germany, Guatemala, El Salvador, Ecuador, Israel, Hong Kong, Italy, Japan, Mexico, Panama, Paraguay, Russia, Spain, Sweden, Taiwan, Ukraine, USA, Venezuela.

\section{Extraction and collectors}

The collection and trade of uña de gato is done by a number of independent entrepreneurs, to fully established enterprises. Inside Peru there are two types of entrepreneurs and companies: Those that engage in the extraction and sale of uña de gato bark, so called centros de acopia, or collection centers and those that engage in the marketing of uña de gato final products. Regarding the sale of the raw material, functions between collection centers and manufacturers may overlap, as some of the large, Lima-based companies do also wholesale uña de gato bark to foreign companies.

For the purpose of this report, we only visited two persons engaged in extraction of uña de gato, one in Iquitos, and one in Pucallpa. One uña de gato trader in Iquitos owned a Contrato de Extraccion (extraction contract, see below) with eight forest products listed in it. However, currently this trader only sells four products: uña de gato, sangre de grado, aceite de copaiba, and jergon sacha. The contract is for $7000 \mathrm{~kg}$ of any combination of the eight products that are mentioned in the contract. This trader informed that $1,500 \mathrm{~kg}$ of uña de gato was sold with a Guia de Transporte, the permit needed to trade any forest product (see below), for an amount of S/. 2.5/kg (at that time about US\$ 1.00) but an additional 9 to 10 tons were sold without such a permit, but for a price of $S / .1 .5 / \mathrm{kg}$. This is an unusual case as most trade, especially to Lima, is done with correct permits, as control on trade in natural resources is very strict. The "illegal" trade that occurs with uña de gato is most likely between intermediaries, meaning that most of the uña de gato collected is eventually being traded with permits. Additionally, bags with uña de gato are sold at home and at one other outlet in Iquitos.

This trader obtained the raw material from a village at the Ucayali river. In this village, the trader has three people who harvest the product themselves, but also contract other villagers. In Iquitos they receive $S / .1 / \mathrm{kg}$. The trader communicates with these three people through the radio, and is visited by them when they come to Iquitos.

A second trader from Pucallpa sold 27 tons in 1994, 16 tons in 1995 and only 5 tons in 1996. When interviewed in January 1997 he had 8 tons of unsold uña de gato in stock. When interviewed again in June 1997, this same amount still remained. Prices are too low to sell it wholesale, hence he planned to sell this amount in small bags of $100 \mathrm{gr}$. Previously this trader sold to Uña de Gato del Peru, a company that now collects uña de gato bark from the Perené valley, in the Satipo area.

The Pucallpa trader has four locations from which bark is collected: Calleria, Utquinia, Roboya, and Cashiboya. The best sites are Utquinia and Calleria. This trader only looks for personnel when bark is needed. Collectors are paid per $\mathrm{kg}(\mathrm{S} / 0.2$ to $0.5 / \mathrm{kg})$. Their transportation is paid, they stay in tents provided by the trader, and they are provided with food. When paying $\mathrm{S} / .0 .2 / \mathrm{kg}$ to the collectors, the total costs of the trader getting the bark outside the forest is $\mathrm{S} / .0 .5 / \mathrm{kg}$. His transporation costs to Lima are $\mathrm{S} / .0 .2 / \mathrm{kg}$, plus cost of several permits (S/. $0.1 / \mathrm{kg}$ canon forestal, $0.1 / \mathrm{kg}$ for the Guía Forestal) and S/. 0.1/kg goes to other expenses. This results in a total cost delivered to the buyer in Lima of S/. 1.0/kg. Currently buyers come to this trader's house to offer S/. 0.5 to $0.7 / \mathrm{kg}$. The costs of the Contrato de Extraccion contract had increased from S/. 600 in 1994, S/. 800 in 1995, to S/. 1800 in 1997.

Carrasco (1996) measured harvesting levels and labor investment for independent collectors who trade the bark that they collect directly with intermediaries. They received between $\mathrm{S} / .0 .5 / \mathrm{kg}$ and $\mathrm{S} / .1 .0 / \mathrm{kg}$. He calculated a total investment of 18 labor hours (2.250 days) for the collection of $43 \mathrm{~kg}$ of wet bark, which converted to 28 $\mathrm{kg}$ of dry bark. He also calculated a per $\mathrm{kg}$ production cost of between S/. 1.33 and S/. 1.67, while average prices received were only $\mathrm{S} / .0 .75 \mathrm{~kg}$. According to this calculation, it is more profitable for collectors to work for intermediaries, rather than to collect independently. 


\section{National manufacturers and their trade}

We interviewed representatives of seven companies, six located in Lima, and one in Pucallpa, that manufacture derivatives from uña de gato. All, except for the company, Tracker S.A. started producing and selling derivatives less than three years ago, and some even less than one year ago. Companies differed in the type of products they sold, tablets with uña de gato extract, obtained through lyophilization (freeze drying), atomization or simply dehydration, capsules with pulverized and micro-pulverized uña de gato, sachets with micro-pulverized uña de gato, hydro-alcohol extract of uña de gato, uña de gato bark packed in small amounts, as well as bark that was cleaned, but not further processed. Several companies sold or had sold bark to foreign buyers. However, there appears to be a tendency towards the sale of processed bark, be it as micropulverized bark, or even lyophilized, or atomized extract. One company produced uña de gato derivatives in combination with shark's cartilage, and another with achiote (annato) extract. Several companies produce a beverage using locally produced sugarcane rum with uña de gato. One company actually utilized the whole stem, bark and wood, for production of micro-pulverized capsules, as it claims that content of therapeutic compounds is only slightly lower in wood versus bark. This same company also claimed to have a test to verify whether if the product is indeed uña de gato or not.

Peruvian companies obtained their raw material directly from collectors, from intermediaries, or in dehydrated form from another company. One company claimed it obtained the raw material from its own estates. Two companies provided information about the amount of bark they had bought. One bought $20,000 \mathrm{~kg} /$ year, while another one had only bought $1,000 \mathrm{~kg}$ since it started selling uña de gato one year ago. They paid prices from $\mathrm{S} / .1 .00 / \mathrm{kg}$, directly to collectors, to $\mathrm{S} / .3 .5 /$ $\mathrm{kg}$ to intermediaries. Three companies had their own Contrato de Extraccion. Two companies informed that they had been engaged in planting uña de gato, one as plantations, one other as high forest enrichment. Two companies are engaged in in vitro propagation research to produce their own raw material.

Only scattered information could be obtained about the weight of derivatives or processed bark that was sold. One company reported to sell 2,000 boxes with 30 tablets per month that contain dehydrated uña de gato extract. This extract was bought from another company. A third company sold 15,000 bottles of tablets and capsules per month abroad, and about half of that amount inside Peru. One other company informed that it sold US\$ 1.5 million of uña de gato derivatives in two years.

\section{United States manufacturers and distributors}

Within the United States there are approximately 12 manufacturing laboratories processing uña de gato into capsules and other mixtures. The manufacturers obtain uña de gato by importing directly from Peru, buying from another supplier who has imported it into the US, or a combination of the two. An informant has reported that each laboratory has the capacity to produce 3 million capsules per day. Manufacturers place the labels on the product for the companies who distribute it throughout the United States. There are at least 39 different companies who distribute uña de gato to health food stores where the consumer buys it. In addition to capsules, uña de gato bark is cut and sifted to make teas. A quote of US \$6.6 per $\mathrm{kg}$ has been given as the price for the finished cut product. Distributors sell to retailers at prices ranging from approximately US $\$ 5.00$ to US \$ 12.00 for 60 tablets of $500 \mathrm{mg}$ with a corresponding retail value ranging from US $\$ 9.00$ to US $\$ 20.00$. For 24 teabags the wholesale price is about US $\$ 4.60$ which retails for US $\$ 7.00$. The capsules and tablets are manufactured in different concentrations (e.g. $250 \mathrm{mg}$, $500 \mathrm{mg}$ ) and may contain, for example, the powdered bark or bark extracts. The initial market boom of uña de gato has declined, however, manufacturers are reporting that demand is remaining steady for uña de gato within the United States and that the same is true of the European market.

\section{Sustaining the resource}

\section{Controlled extraction and management of uña de gato}

Uña de gato has been and still is being harvested mainly from natural stands, mostly in high natural forest. In many cases, this extraction is done with little concern to assure a sustained supply of this natural resource. There are, however, some examples of controlled harvesting, with such an objective in mind. Jones (1994, cited in Duke 1994) reports on the habit by Ashaninka children to plant two vines for every stem they harvest. The most elaborate example of controlled harvesting is found among Yanesha inhabitants of the Palcazu valley, central selva of Peru. In 1990, with the help of Pro Naturaleza the inhabitants of the Yanesha community Loma LindaLaguna began efforts to sustainably harvest uña de gato from their territories. The village had 170 ha of forest reserved for the extraction of forest products. In order to sustainably harvest uña de gato, inventories were conducted in $3.5 \%$ of these 170 ha, measuring dbh and length of Uncaria individuals. Permanent plots were established in harvested areas to monitor the impact of harvesting on the population, and some clearing of the area around seed producing uña de gato individuals was done to encourage germination of seedling in the forest.

The inventory of the three hectares resulted in a density of 17 individuals/ha, with a calculated total bark surface of $434.08 \mathrm{~m}^{2}$. The total weight of fresh bark in the 170 ha was calculated as $82,110 \mathrm{~kg}$. It was decided 
that only $60 \%$ of the uña de gato population should be touched, hence an amount of 49,266 kg of fresh bark was to be harvested. As the villagers estimate that it takes 10 years for an uña de gato seedling to reach maturity, a growing and harvesting cycle of that time period was decided upon. Hence per year only 5,000 $\mathrm{kg}$ fresh bark is to be harvested. This will result in an amount of a little over $3,000 \mathrm{~kg}$ of dried bark that can be harvested yearly from the Loma-Linda Laguna forest reserve. Uña de gato vines are to be cut at $1 \mathrm{~m}$ height to assure their regrowth potential. At intervals, clearing of competing vines is done (Arce 1996). Although the uña de gato that was cut did resprout, seed germination is low in these areas.

A similar procedure of restrained harvesting is followed by Liofilizadora del Pacifico/Omniagro, a Peruvian company that produces the uña de gato derivatives that are sold under the name Manax. The company has made an agreement with a native community in Pauja, southern Ucayali Region, near Sepagua. The inhabitants of this community, together with officials from the Ministry of Forestry performed an inventory of an area of forest near the village. This area was zoned, and a harvesting plan was made to follow a harvesting cycle of one zone per year. It is expected that this will allow for a continued supply of uña de gato. The US company Peruvian Rainforest Botanicals buys from Ashaninkas who harvest uña de gato cutting stems at $1 \mathrm{~m}$ height to allow plants to regenerate.

\section{Government actions to sustaining production}

Forestry officials and conservationists in Peru are encouraging people to propagate uña de gato. For instance, on August 29 and 30, 1994 in Pucallpa an event, Uña de gato, planta medicinal nativa de la Amazonia Peruana, was organized by the Comite de Reforestacion de Pucallpa to make known the qualities of uña de gato, promote its silvicultural management and encourage its planting. Information was provided on commercialization and markets of uña de gato. One of the objectives of this event was to look for alternatives to its "irrational" exploitation in the Peruvian Amazon.

The reforestation committees in Iquitos and Pucallpa have been or still are engaged in promoting replanting of uña de gato. In Iquitos, for instance, the Reforestation Committee provided 10,000 uña de gato plants, as part of a total of 150,000 seedling delivered to the Comunidad Nativa Pauyan, in Contamana. This was planted at distances of $5 \times 10 \mathrm{~m}$ in natural forest. Currently, the Reforestation Committee in Iquitos does not provide any plants anymore, but rather facilitates reforestation through village initiatives, initiatives by municipalities, or NGOs. The Reforestation Committee in Pucallpa still provides uña de gato seedlings. Until 1996, 200 ha of land had been reforested using Uncaria tomentosa. That same year an additional 110,192 seedlings were provided to farmers for reforestation and were mostly planted in old fields. An additional planting of 280,000 seedlings is planned. These seedlings are collected from the wild, as germinating seedlings has still been unsuccessful. Peru has named 1997 as the Reforestation Year in which it plans to plant 100 million trees, including 10,000 ha with uña de gato.

One trader in Pucallpa informed us that he has planted 4 ha of uña de gato in secondary forest in a location called Porvenir, with seedlings from the Reforestation Committee. He has made small strips inside the forest and has planted at distances $5 \mathrm{mx} 5 \mathrm{~m}$. In about 5 years these seedlings are expected to have a dbh of $15 \mathrm{~cm}$. A minimum of $10 \mathrm{~cm}$ is needed to harvest uña de gato, but according to the informant, the reduction from fresh to dry weight of individuals of that size is about $70 \%$ which significantly reduces the yield from a harvest.

\section{Root versus bark}

There is disagreement regarding the harvesting of uña de gato root versus stem bark. The debate revolves around the ecology of the plant, the legality of root extraction and its active compound concentrations. Ecologically, it is assumed that any harvesting of the root will destroy the plant and such harvesting would threaten the species' populations. Studies, however, are necessary to investigate the effects of root harvesting on regeneration. Harvesting of root is technically legal based on a Peruvian law (Decreto Ley Numero 21147 y sus reglamentos de conservacion de flora y fauna silvestres y de extraccion y transformacion forestal) which does not explicitly prohibit such harvesting; however, it is necessary that INRENA issue permits for such root harvesting, but to date INRENA's policy is not to issue such permits for root harvesting. Some of the root product on the market does come from plantations rather than the wild. There are claims that the root bark has a greater concentration and quality of active compounds. It is true that many of the studies of the chemical composition of uña de gato were performed with root bark (e.g. Laus and Kepplinger 1994, Montenegro de Matta et al 1976). It has been stated that the root bark taken from one plant has the equivalent concentration as stem bark taken from four plants; whereas others say that the roots are too thin and that a large quantity of root material would be necessary. If this were true, there would be implications that harvesting fewer plants for root bark might have less of an impact on the overall forest ecosystem as fewer plants would be harvested.

\section{Uña de gato propagation techniques}

Considerable research has been done on developing propagation techniques of uña de gato. The three institutions that have spent efforts on this research are 
the Instituto de Investigaciones de la Amazonia Peruana (IIAP, e.g. Quevedo 1995), the Inistituto Nacional de Investigacion Agropecuaria (INIA, e.g Flores 1995), and the Universidad Nacional Agraria La Molina (UNALM).

Propagation of uña de gato can be conducted through the collection of seeds, which are planted in nurseries, and then transplanted onto their final site. Propagation can also be conducted using 20 to $30 \mathrm{~cm}$ long cuttings with a 3 to $5 \mathrm{~cm}$ diameter. These cuttings can be planted in a slightly inclined vertical fashion in the final location without any need for transplanting. Only cuttings from branches, and not from the principal stem should be used (Quevedo 1995). Insufficient evidence still exists about the speed of maturing. Quevedo (1995) believes the silvicultural cycle of uña de gato is about five years, while Schunke 1994 (cited in Zavala \& Zevallos 1996) believes the cycle to be three years for individuals planted as cuttings and six years for individuals planted using seeds. Yanesha uña de gato collectors wait a minimum of 10 years for a plant to reach a commercial size.

UNALM, the INIA's Programa Nacional de Recursos Geneticos and private companies (e.g. Tracker S.A.) have successfully been conducting experiments with micro or in vitro propagation. In this procedure, tissue is obtained from micro-buds and stimulated to proliferate using growth regulators. This technique is believed to allow to control or improve the active compound content. According to Dominguez (1997) in vitro propagation has the advantage that identical propagation of selected progenitors can be produced, genetic conservation of the species is assured, standardization and improvement of quality of raw material is possible, selected progenitors can be propagated, and large numbers of plants can be produced within a short time.

The assumptions of in vitro propagation's benefits do not take into account the possibility of the environmental effects on active compound content. There is ample evidence that such an effect exists as this, for instance, may explain why Peruvian uña de gato is claimed to be of better quality than uña de gato from elsewhere. It has been found that individual plants switch alkaloid patterns over the years (Laus \& Kepplinger 1994). Much more research needs to be done on the relationship between environmental factors and active compound content, including for in vitro propagated material.

\section{Policy and legal issues}

\section{Permits and administration for collection, trade and export of uña de gato}

The harvesting and trade inside Peru requires two types of permits: The Contrato de Extraccion if extraction is to be done from public forests, or a Permiso de
Extraccion if forest products are to be harvested from Comunidades Nativas or Unidades Agropecuarias. If any forest product is to be transported or traded inside Peru, than a Guia de Transporte is needed. For the exportation of any forest product for commercial purposes, a Permiso de Exportacion is necessary. The requirements for each of these legal documents are explained below as found in Ascencios Vasquez 1996.

The requirements for a Contrato de Extraccion are (1) a formal request which has to include (2) a map of the area to be exploited, (3) an estimate of the units of the forest products to be extracted, and (4) an indication of the period of extraction. If the request concerns areas larger than 10,000ha, then a Contrato de Exploracion y Evaluacion de Recursos Forestales has to be obtained first.

A Permiso de Extraccion Forestal needs (1) a formal request that states the products, the estimated amounts to be harvested, and the numbers of subsequent harvests. It also has to include (2) the dates of the meetings during which the extraction was agreed upon, and (3) the number of participants in those meetings, and the number of persons who will be doing the extraction. Both contracts and permits of up to 1,000 ha may be authorized by the Director of the Agricultural Agencies. Contracts and Permits for over 10,000 ha have to be authorized by the Director Regional Agraria, through a Ministerial Resolution.

Commercial establishments and deposits of forestry products have to be registered in the Registro de Establecimientos Comerciales y Depositos de Productos Forestales. This can be done through a request directed to the Director of the Direccion Regional Agraria and needs to include the license that was given by the Municipality, as well as a map of the location of the establishment.

Four types of objectives of exportation are recognized by INRENA: commercial, scientific, cultural or as a pet. For commercial export the requirements are: (1) a copy of the registration of the company in the Registro de Establecimientos Comerciales y Depositos de Productos Forestales of Commercial; (2) a copy of the Registro Unico de Contribuyente; and (3) a copy of the company's constitution. Items 1, 2, and 3 only have to be presented the first time a permit is requested. Additionally (4) a request needs to be filed with the Director of INRENA that contains (5) the original receipt for the payment of the right to extract, (6) the original Guía de Transporte, (7) a certificate of identification or certificate of primary transformation, and (8) a receipt for the payment of exportation permit.

\section{Genetic and intellectual property rights}

The laws or international agreements that regulate access to natural resources like uña de gato are Peru's Constitution, the Codigo del Medio Ambiente, Decision 
391 on the Regimen Comun sobre Acceso a los Recursos Geneticos of the Cartagena Agreement (soon to be replaced with a new Peruvian law on Access to Genetic Resources), the Biodiversity Convention, and the Convention 169 of the International Labor Organization. Additionally a new Law on Medicinal Plants is being proposed.

Other laws and agreements valid in Peru that deal with property rights in general are mainly of the type of patent legislation or protection of the rights of the inventor or author. This type of legislation or agreement very much emphasizes that the product or process for which intellectual property right is claimed needs to be new. Article 66 of Peru's Constitution states that natural resources, renewable and non-renewable are the patrimony of the Nation. The state is autonomous in its benefit capturing of these resources, but, through organic laws it has to establish the conditions under which these resources can be given in concession for exploitation to private entities. Article 46 of the Codigo del medio ambiente states that the state can prohibit the exportation of genetic resources in the cases that it considers necessary (Cayllaux Zazalli 1994).

An important agreement that defines in more detail state property over genetic resources is the Decision 391 on the Regimen Comun sobre Acceso a los Recursos Geneticos taken by the members of the Agreement of Cartagena. This decision establishes that each country is sovereign over the genetic resources that are contained inside the country and if such a resource originates from within the country, then it is the patrimony of the state. At one point Peru was considering withdrawal from the Cartagena Agreement, but now a new law that regulates access to genetic resources has been published. The intention of the legislation on access to genetic resources is that a legally established body will consider formal requests of access to genetic resources, and that only if such requests are submitted and accepted, will any utilization of genetic resources be allowed. The legislation specifies in detail the conditions under which this use is permitted.

The Convention 169 of the International Labor Organization recognizes intellectual property rights of native groups over knowledge they solely hold. In the Decision 391 this issue is also very much emphasized. A detailed procedure is being developed to deal with cases where several organizations are involved with recording and putting to some kind of use indigenous knowledge on natural resources (e.g. Ruiz 1996). Most importantly, any request for utilization of genetic resources has to indicate the source of information and, in cases where this information has been provided by indigenous groups (Amerindians, or Campesinos), the compensation agreement that has been established for the providing of the knowledge.

Cayllaux Zazzali (1994) argues that besides newly transferred knowledge from indigenous groups to society at large, compensation also should be considered for previous use of indigenous knowledge, as this was often provided without knowing the implication this might have in terms of losing the sole access and therefore, bargaining power over that knowledge. This opinion, however, only partly resolves the complicated issue of existing patents related to uña de gato. There are three patents known to us. One was given on July 4, in 1989 to Klaus Keplinger, Hildebert Wagner, and Barbara Kreutzkamp titled "Oxindole alkaloids having properties stimulating the immunologic system" (United States Patent Number 4,844,901). The second patent (United States Patent Number 4,940,725) has the same title and is of July 10, 1990. A third patent is from April 12, 1994 and was given to Klaus Keplinger, and Dietmar Keplinger for the "Oxindole alkaloids having properties stimulating the immunologic system \& preparation containing the same" (United States Patent Number $5,302,611)$. The patents deal with the extraction process of some of the compounds of uña de gato, which is a discovery that is entirely a result of the intellectual efforts of the patent holders. On the other hand, information concerning the possibility that uña de gato contains such compounds was provided by inhabitants of remote villagers in Peru. As such, these transfers of information should still be compensated if one were to agree with the opinion of Cayllaux Zazzali concerning this issue.

\section{Resolving the issues}

\section{Is the resource base being threatened?}

The impact of some kind of exploitation of a renewable natural resource depends on two main factors: (1) how much of the resource is being harvested compared to its population size, and (2) how quickly can the species reproduce itself under this level of harvesting. In the case of uña de gato, the first question is difficult to answer, mainly because we do not know how much uña de gato there is. However, it is known how much uña de gato was exported for the past three years and that this constitutes an estimated $95 \%$ or more of all the uña de gato harvested. This allows for an estimate of the area of forest from which uña de gato has been harvested and some statements on the expected harvesting impact.

An individual with $8 \mathrm{~cm}$ diameter yields $0.55 \mathrm{~kg}$ of dried bark per one meter of stem. The harvestable length varies in relation to diameter. The average length of an $8 \mathrm{~cm}$ dbh individual is $19.71 \mathrm{~m}$ (Carrasco 1996), but $27.9 \mathrm{~m}$ for individuals with $\mathrm{dbh}$ of $10 \mathrm{~cm}$ (Domingues 1997). It is estimated that single individuals have between 13.26kg (Carrasco 1996) and $15.34 \mathrm{~kg}$ (Domingues 1997) of dried bark. Under conditions with two individuals per ha, total production, therefore, is between $26.52 \mathrm{~kg} / \mathrm{ha}$ and $30.64 \mathrm{~kg} / \mathrm{ha}$. Using these calculations, the 726 tons of uña de gato exported in 1995 were harvested from an estimated area of 23,716 
to 27,400 ha of forest. On the other hand, the 17 individuals/ha that Pro Naturaleza found in its inventories in Yanesha in the Palcazú valley, $306 \mathrm{~kg}$ of bark could be harvested per ha. With such a density and yield levels, only 2,374 ha would have to be harvested to obtain the 726 tons collected in 1995. Using the lower density estimates of uña de gato, the total weight exported over the four years reported in table 1 would have been harvested from an estimated 41,272 ha.

The total area of Peru's closed moist tropical forest is some 70 million ha. Of this total, almost 44 million ha are lowland tropical forest on interfluvial areas with an altitude up to $800 \mathrm{~m}$ asl. We do not know how much of this forest contains uña de gato. If we were to assume that this species would be found in the entire area of this forest with 2 mature individuals per ha, then harvesting 726 tons from 34,000 ha per year cannot be expected to threaten the species within a short time horizon

An additional important factor to assess the impact of current exploitation levels on the resource base is the reproductive behavior of any of the two uña de gato species. They are both light demanding species, and both thrive in disturbed or secondary forest, although Uncaria guianensis more so than Uncaria tomentosa. As a result of conversion of the forest land to swidden agriculture, a significant proportion of the land is under fallow, a habitat in which both species can multiply much faster than under natural conditions. The absolute number of individuals in the total Peruvian territory has therefore most likely increased rather than decreased over the last four years that the species has been harvested intensively.

Furthermore, if one adult individual of uña de gato yields $15.35 \mathrm{~kg}$ of dried bark, then the total weight of 1,094,530 that has been exported from 1993 to 1996 did originate from an estimated 71,305 adult individuals. The number of uña de gato seedlings that has been planted or replanted exceeds by far this number of individuals harvested. Again given this estimation, uña de gato is not at risk for biological extinction.

These conclusions need to be verified with appropriate research, as they are based on assumptions or scant data. However, they do indicate that with current exploitation of the resource there is little threat that any of the uña de gato species will be put to biological extinction mainly because of their reproductive behavior. It may therefore be argued that at this moment no specific measures should be taken to limit exploitation of uña de gato from natural forest for reasons of protecting the exploited species from over-harvesting that might threaten its biological survival. It might even be argued that it was premature to put uña de gato in the category of vulnerable species, the category in the Reglamento de Conservacion de Flora y Fauna Silvestre to distinguish species that may soon enter the category threatened with extinction because they are overharvested, or because their habitat is being destroyed. Before such measures are to be taken, more information should be gathered on the impact of harvesting, as there appears to be sufficient time available to get a better idea of such impact. On the other hand, guidelines should be set for best management practices to avoid over-exploitation which may have or could occur in localized areas.

As mentioned before, it is not known whether there are any species that depend on uña de gato for their life cycle, and that are subsequently affected by its harvesting. This also should be investigated.

\section{The future of the industry}

Considering that at current exploitation levels, there appears to be no imminent threat to the supply of uña de gato, and that several manufacturers have advanced plans to produce their own raw material, the future of the Peruvian industry of uña de gato suppliers and producers of derivatives depends largely on developments of the markets, and on possible competition from manufacturers in other countries. The market developments appear to be good for derivatives. Future sales can most likely be sustained or increased, as long as quality is assured. Probably, with the development of improved raw materials, the existing markets can most likely be strengthened.

The largest part of uña de gato sales abroad still is as unprocessed or processed bark. Current trends indicate that in the future, a larger share of uña de gato sales will be as extract to the largest buyer, the US. It is not clear to what extent Peruvian companies will be able to increase their share of manufactured products in markets outside of the country. On the one hand, manufactured products in Peru will be more expensive to ship to other countries than will the extracts. On the other hand, production costs in Peru may be lower than, for instance, in the United States. It will be useful to compare the two options. When it appears that the lower costs of manufacturing inside Peru outweigh the higher transportation costs of shipping these products to international markets, especially the United States, then Prompex (the Peruvian government agency promoting exports), or other agencies, could pay special attention to introducing Peruvian-produced uña de gato derivatives in those markets. It will also be useful to analyze in more detail what the difference is in benefit capturing between the sale of unprocessed bark, semiprocessed bark or extracts, and manufactured products.

On the other hand, whether it will become profitable for non-Peruvian, national enterprises to acquire uña de gato extracts to locally manufacture medicines, will depend on the volumes of sales in individual countries that have comparable labor costs. There is probably a 
minimum volume, below which it will not be profitable to do so. A possible scenario could be, however, that the Peruvian uña de gato industry was to become a victim of its own success, when increased international demand will result in an increased demand of uña de gato extract for the production of medicines in foreign countries.

\section{Benefit capturing among small-scale collectors}

The future of benefit capturing for small-scale collectors would vary according to several possible scenarios that may take place. We have no correct numbers of how many small-scale collectors actually participate in the uña de gato collection, but total yield data do give some indication. If in 1995, the 726 tons of dried stem bark were obtained from about 1,200 tons of wet bark, and we calculate that an uña de gato collector can harvest $50 \mathrm{~kg}$ of wet bark per day, then this means that some 24,000 labor days had been spent collecting this weight. If it is calculated that each collector would have received a net profit of $S / .0 .2 / \mathrm{kg}$, then each collector would have received $\mathrm{S} / .10$ for every day he or she collected uña de gato, which is currently the minimum wage in Peru. If one were to assume an additional post-harvesting treatment of $50 \%$, resulting in a total occupation of 36,000 labor days, and were to calculate full-time employment as 250 labor days per year, then the harvest of 726 tons of dried bark would correspond to full-time employment of about 144 persons per year. Considering that the primary occupation of the collectors is farming and that the purpose of uña de gato harvesting is to supplement their income, it is expected that the number of people benefitting is much greater than 144 .

These incomes can be sustained or increased if demand remains the same or increases, and if uña de gato is supplied from plantations owned by farmers. There are no figures for the labor investment necessary for the production of uña de gato in swidden fallows or other types of plantations. However, considering the low intensity with which uña de gato can be produced, it is unlikely that the labor expenditure would be much greater than when the product is collected from distant forests. Production of uña de gato in swidden fallows will give small-scale collectors greater control over the resource, and may subsequently allow them to capture a larger share of the benefits, if market prices were to remain the same.

Shifting from forest extraction to cultivation of uña de gato will most likely influence prices, because of a possible oversupply. If uña de gato is planted at distances of $5 \mathrm{mx} 5 \mathrm{~m}$, as is already done by the Comite de Reforestacion, then 361 individuals of the species could be produced on a single hectare. Assuming that in six years these individuals were to have a $10 \mathrm{~cm}$ diameter, and using the $70 \%$ reduction in weight that has been suggested for individuals that are planted, for instance in secondary forest, then these individuals could yield up to $5 \mathrm{~kg}$ of dried bark per plant, or about $30 \%$ of what a primary forest individual can yield. Even if a secondary forest individual were to yield only $10 \%$ of this weight, or $1.5 \mathrm{~kg}$ per individual, then the total area of planted uña de gato would add up to only about 1,340 ha to supply the 726 tons that were harvested in 1995 . The 1,340 ha would be planted with about 500,000 uña de gato plants. Eighty percent of this amount is already planted, or projected to be planted within the near future by the Comite de Reforestacion in Pucallpa. Assuming that one small-scale producer were to have one hectare planted in uña de gato and harvested one-sixth of this hectare every year, then about 8,000 small-scale producers could benefit from a similar uña de gato production. This would be a relatively small number, and would create a significant danger of overproduction and a subsequent decline in prices that producers possibly could receive.

Another danger that is looming for small-scale producers is the shift towards the production of the raw material by manufactures and traders themselves, or even the shift to in vitro production of large amounts of tissue in laboratories. Were manufacturers and export firms entirely to produce the uña de gato they use or sell abroad, using in vitro reproduction of seedlings, then this would significantly reduce the benefits to smallscale collectors, unless the production were to be contracted out to or produced under partnership agreements with those small-scale collectors. In the latter case, collectors will have much less bargaining power over price levels, hence the incomes obtained per $\mathrm{kg}$ would be expected to decline. If mass reproduction of tissue under in vitro conditions were to become the preferred option, then small-scale collectors would lose out entirely on the business.

On the other hand, if manufacturers were to take over the bulk of the production of uña de gato, then still an important niche could remain for so called "green" production of uña de gato to supply a specialty market. This would be a market for real uña de gato bark collected from naturally reproduced vines, or produced under conditions that benefit small-scale collectors. It can be expected that the volume of this market would be relatively small, although this would have to be investigated.

\section{Compensation for property rights}

The difficulties with trying to provide compensation for intellectual or genetic property rights are on the one hand the distribution of the genetic resource over a large number of South American countries, and on the other hand the widespread knowledge of its healing qualities and the utilization of uña de gato as a folk medicine. Especially now that Peru has accepted a law that restricts export of improcessed uña de gato material, it will be 
more difficult to negotiate any agreement with an interested party to compensate for the genetic resource. Parties always can decide to negotiate with other countries. A similar problem occurs if some kind of recognition were to be sought for the intellectual property rights of indigenous people for uña de gato. As it is not clear at all who discovered the healing potential of uña de gato, it would have to be rather an arbitrary selection of one group to hold the intellectual property rights, excluding others who also know about these species. This problem could be resolved if indigenous and farmers groups were to agree on a shared intellectual property right for uña de gato.

\section{The proposed export ban}

Several Peruvian pharmaceutical companies have been lobbying for an export ban of unprocessed uña de gato. This ban has been accepted although we have not been able to study the new law yet. There are three categories of material, raw or unprocessed bark, semi-processed in which, for example, the bark has been cleaned of micro-organisms and finished product such as capsules.

In country processing will certainly add-value to exported uña de gato and in theory would increase income for Peruvians. However, in order for such profit-making to occur certain conditions will be necessary, for example: (1) that Peruvian industry has the capacity to process large volumes of uña de gato; (2) that the products are manufactured under strict quality-controlled conditions that would be approved for import into other countries; and (3) that sufficient capital exists for investing in marketing and advertising overseas. At the national level, if the processing were performed and controlled by a limited number of companies, a consequence may be decreased for collectors and increased prices for consumers with profits captured by the manufacturers.

It is certain that the initial reaction of US importers (to date the largest importers) to an export ban would be to obtain uña de gato from other Amazonian countries or Central America. Furthermore, in vitro culture of uña de gato is occurring in the United States. If this becomes scaled up to commercial production, there may be no need to import Peruvian products of any kind, processed or unprocessed. In either of these scenarios, trade with Peru would diminish greatly or stop entirely.

A further consideration is that any products imported into the US have to be fit for human consumption and approved by the Food and Drug Administration and U.S. Department of Agriculture Customs. If claims are made of the curative properties of the product, then more stringent tests are required for entry. Other countries besides the United States also have conditions for accepting imports.
Even if the Peruvian finished product entered the United States, it would have to capture the demand of the US consumer. There is the strong possibility that the US consumer will not have as much confidence in a foreign-made product as a US-made product because US laboratories follow strict quality control regulations set out by the US Food and Drug Administration. Furthermore, the US consumer often is warned of the dangers of consuming foreign-made pharmaceuticals and Peruvian pharmaceuticals would have to overcome the consumer's fear of such products.

One would have to rethink carefully restricting the export of uña de gato. A ban on crude raw material would probably be less damaging to Peruvian exports because many U.S. manufacturer's would still actively buy semi-processed material. If the export ban were to exclude all but finished processed products (e.g. capsules), then there would be a loss in the US market demand from manufacturers and consumers. Rather, the Peruvian manufacturing industry should try to increase its effectiveness, competitiveness, provide reliable, high quality products and establish healthy and long terms contacts in countries where uña de gato products are being sold. This will take much careful planning and advertising, as Peruvian processed uña de gato products may find themselves at a competitive disadvantage in the larger USA and European markets. In these countries consumers look towards products manufactured in their own countries under strict quality-controlled conditions and may as a result distrust foreign-made products. With the demand having fallen from 1995 levels, there is a question whether a large investment by the Peruvian manufacturing industry would actually pay-off.

\section{Conclusions}

In this paper we have discussed a broad number of issues that relate to the harvesting, production, trade, manufacturing, and sale of Uncaria tomentosa and Uncaria guianensis, the two species known as uña de gato. These two species have been investigated by ethnopharmacists for several decades, but only in the last four years has their harvesting and trade increased dramatically. The most important conclusion of this preliminary assessment is that the future and fate of uña de gato is for the largest part being driven by the market of the raw material and its derivatives. There appears to be little ground for the argument that any of the two species is threatened by biological extinction in the near future due to its "irrational" use, although overharvesting may occur in localized areas. Even with the increased harvest of uña de gato that has taken place over the last few years, there appears to be more than sufficient time to establish the maximum harvesting levels beyond which the resource becomes biologically threatened. It is not clear how large is the danger of 
economic over-harvesting that would cause an exhaustion of this natural resource from accessible areas. This could lead to an increase in price for the raw material if it has to be obtained from greater distances and if no alternative production systems have been established.

The current quantities of uña de gato sold do not justify large-scale promotion of planting of uña de gato, as this will hold the risk of over-production and the subsequent collapse of prices. The current market trends, however, give justified hope that future sales will increase and that increased future demands have to be anticipated. The difficult question to be resolved is who will bear the risk of investing in planting uña de gato, while not knowing whether it can be sold at reasonable prices once it has reached adequate sizes.

One option that should be explored is the willingness of private companies in Peru to engage in some kind of coordinated or contracted production of uña de gato in secondary forests with small-scale collectors that uses plant material that has been reproduced through in vitro technology. Tracker Company, for instance, mentioned plans to produce 200,000 plants of selected genetic material, that it expects to plant with the help of smallscale collectors.

The extent to which small-scale collectors or producers will be able to benefit from possible future demands depends largely on whether the private industry wants to take uña de gato production into its own hands through planting in vitro reproduced seedlings, and whether in such a scenario there will still be a role for small-scale producers. Were the industry to shift to in vitro mass production of tissues, then small-scale collectors and producers would lose out by no longer having any role in the collection, production, and trade of the raw material. In that case, however, still a small market niche can expected to remain for "green" produced uña de gato, for instance by selling uña de gato collected by indigenous people, or as unprocessed bark for people who prefer to prepare their own decoctions. It is not impossible that eventually uña de gato produced under natural conditions will prove to be more effective.

It is important that more research be performed to better understand future market trends and to accurately assess the risk to small-scale producers in uña de gato plantation schemes. This assessment should be used to adjust these schemes or better inform farmers of what the prospective of allocating scarce resources to planting uña de gato are.

It can be concluded that uña de gato holds a potential that is still not entirely exploited. However, several of the issues brought up in this paper will need better data to sustain or contradict conclusions proposed here. The current importance and apparent potential of uña de gato justify such additional data collection. Research will have to be conducted on the ecology of uña de gato, including its population dynamics, reproductive behavior, distribution in Peru, as well as changes in compound contents in relation to environmental factors. It is imminently important to try to obtain much better data on the benefit capturing, collection, and trade networks inside Peru, as well as abroad. Especially future market developments should be studied. 


\section{Literature cited}

Aquino, R.; Conti, C. and Stein, M.L. 1989. Plant metabolites: Structure and in vitro antiviral activity of quinovic acid glycosides from Uncaria tomentosa and Guettarda platypoda. Journal of Natural Products 52(4): 679-685

Aquino, R.; De Simone, F.; Vincibri, F.F.and Pizza, C. 1990. New polyhydroxylated triterpenes from Uncaria tomentosa. Journal of Natural Products 53(3):559-564.

Aquino, R.; De Feo, V.; De simone, F.; Pizza, C.; Cirino, G.. 1991. Plant metabolites: New compounds and antiinflmmatory activity of Uncaria tomentosa. Journal of Natural Products 54(2):453-459.

Arce, Javier. 1996. Manejo de bosques para producción sostenible de uña de gato: la experiencia del valle del Palcazu. Presentation at the course: Identificacion, produccion, propagacion, y manejo de uña de gato. Universidad Nacional Agraria La Molina. 13-15 November 1996, Lima.

Ascencios Vasquez, Daniel. 1996. Normatividad de la extraction y requisitos para la exportacion de uña de gato. Presentation at the course: Identificacion, produccion, propagacion, y manejo de uña de gato. Universidad Nacional Agraria La Molina. 13-15 November 1996, Lima.

Balee, William. 1994. Footprints of the forest:Ka'apor ethnobotany: The historical ecology of plant utilization by an Amazonian people. Columbia University Press, New York.

Cabieses, Fernando. 1995. La uña de gato en su entorno. Vía Láctea, Editores, Lima, Peru.

Castañeda, O. et al. 1997. Evaluacion de Uncaria tomentosa en reumatismo extrarticular y osteoartrosis. Presentation at the Simposium on Uncarias, Lima, February 4, 1997. Ministerio de Salud.

Carrasco Arce, Luis Eduardo.1996. Analasis de la estructura de costos de extraccion de corteza de una de gato, Uncaria tomentosa, en la provincia de Puerto Inca (Huanuco). Tesis de Ingeniero Forestal, Universidad Nacional Agraria La Molina

Cerri, R. 1988. New quinovic acid glycosides from Uncaria tomentosa. Journal of Natural Products 51 (2):257-261

Dominguez Jilberto. 1997. Una de gato: Mercado y produccion sostenible. Draft document: Universidad Agraria La Molina, Lima

Duke, James A. 1992. Uña de gato: Numero uno. Unpublished manuscript.

Flores Bendezu, Ymber. 1995. Propagacón por semilla de la uña de gato (Uncaria tomentosa). Instituto
Nacional de Investigacion Agraria, Proyecto suelos tropicales, Lima Peru

Hemingway and Phillipson 1974. Alkaloids from S. American species of Uncaria (Rubiaceae). Journal of Pharmacology 26:113.

INMT. 1997. Simposio de Uncarias, 04 de Febrero 1997. Boletin Ministerio de Salud, Instituto Nacional de Medicina Tradicional, Lima, Peru.

INRENA. 1996. Anuario estadístico de exportaciones de flora y fauna silvestres, Año 1995. Instituto Nascional de Resursos Naturales, Ministerio de Agricultura, Lima, Peru.

Laus,G. and Kepplinger, D. 1994. Separation of stereoisomeric oxindole alkaloids from Ucaria tomentosa by high performance liquid chromatography. Journal of Chromatography A 662:243-249.

Maxwell, Nicole. 1976. Geneeskracht uit het oerwoud (Duthc translation of Witch doctors apprentice.) Amsterdam Boek B.V., Amsterdam.

Mirez (n.d.) Fitoterapia en cancer avanzado.

Montenegro de Matta, S.; Delle Monache, F.; Ferrari, F.; Marini-Bettolo, G.B.t al. 1976. Alkaloids and procyanidins of an Uncaria sp. from Peru. Il farmaco 31: 527-535.

Obregon Vilches, Lida E. 1995. Uña de gato (cat's claw): Genero uncaria, estudios botanicos, quimicos y farmacologicos de Uncaria tomentosa, Uncaria guianensis, third edition. Instituto de Fitoterapia Americano, Lima, Peru.

Pevez, Cesar et al. 1997. Evaluacion de la Uncaria tomentosa en reumatismo extracrticula y osteoartrosis. Presentation at the Simposium on Uncarias, Lima, February 4, 1997. Ministerio de Salud.

Piscoya Jose, et al. 1997. Ensayo clinico doble ciego comparando Uncaria guianensis contra placebo en dosis unica diaria para el tratamiento de osteoartrosis de rodilla. Presentation at the Simposium on Uncarias, Lima, February 4, 1997. Ministerio de Salud.

Quevedo Guvara, Americo.1995. Silvicultura de la una de gato: Alternativa para su conservacion

Instituto de Investigaciones de la Amazonia Peruana, Iquitos, Peru

Rizzi, S. et al. 1992. Mutagenic and antimutagenic activities of Uncaria tomentosa and its extracts. Journal of Ethnopharmacology 38:63-77.

Ruiz, Manuel. 1996. Los recursos geneticos y la integracion Andina. Equilibrio, Julio Octubre 1996. Sociedad Peruana de Derecho Ambiental, Lima, Peru. 
Senatore et al. 1989. Phytochemical and biological study of Uncaria tomentosa. Bollettino Societa di Biologia Sperimentale 65:517-520.

Tobin, Brendan and César Sarasara. 1996. Farmaceutica Searle se obliga a respetar conocimientos etnobotanicos de communidades nativas. Equilibrio: Boletin de medio ambiente y desarollo sostenible, Julio October: 9-10. Sociedad Peruana de Derecho Ambiental, Lima, Peru.

Sandoval, M., E.E. et al. (in press) Cat's claw (Uncaria tomentosa) protects against oxidative stress and indo methacin- induced intestinal inflammation. Louisiana State Universtity Medical Center, New Orleans.

Standley and Williams. 1975. Flora of Guatemala. Fieldiana: Botany, Volume 24.
Vasquez Martinez, Rodolfo. 1989. Plantas utiles de la Amazonia Peruana. Iquitos, Peru

Wagner, H.; Kreutzkamp, B. and Jurcic, K.1985. Die Alkoloide van Uncaria tomentosa und ihre Phagozytose-steigernde Wirkung. Planta Medica 51:419-423.

Yepez, Ana M. et al. 1991. Quinovic acid glycosides from Uncaria guianensis. Phytochemistry 30(5):1635163.

Zavala Carillo, César A. and Percy A. Zevallos Pollito. 1996

Taxonomía, distribución geográfica y status del género Uncaria en el Perú: Uña de gato. Universidad Nacional Agraria La Molina, Facultad de Ciencias Forestales, Lima Peru. 